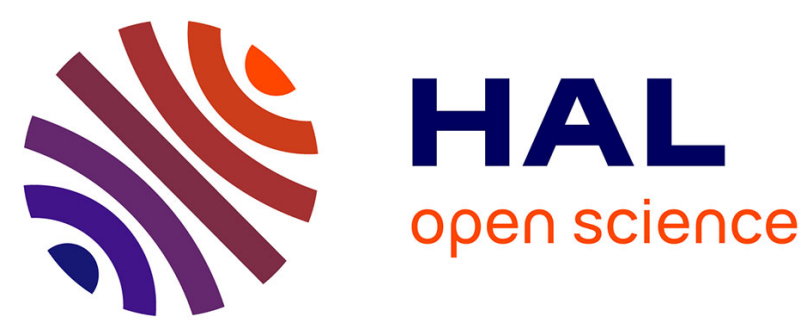

\title{
Influence of food on the assimilation of selected metals in tropical bivalves from the New Caledonia lagoon: qualitative and quantitative aspects
}

Laëtitia Hédouin, Marc Metian, Thomas Lacoue-Labarthe, Renaud Fichez, Paco Bustamante, Michel Warnau

\section{To cite this version:}

Laëtitia Hédouin, Marc Metian, Thomas Lacoue-Labarthe, Renaud Fichez, Paco Bustamante, et al.. Influence of food on the assimilation of selected metals in tropical bivalves from the New Caledonia lagoon: qualitative and quantitative aspects. Marine Pollution Bulletin, 2010, 61 (7-12), pp.568-575. 10.1016/j.marpolbul.2010.06.034 . hal-00511997

\section{HAL Id: hal-00511997 \\ https://hal.science/hal-00511997}

Submitted on 26 Aug 2010

HAL is a multi-disciplinary open access archive for the deposit and dissemination of scientific research documents, whether they are published or not. The documents may come from teaching and research institutions in France or abroad, or from public or private research centers.
L'archive ouverte pluridisciplinaire HAL, est destinée au dépôt et à la diffusion de documents scientifiques de niveau recherche, publiés ou non, émanant des établissements d'enseignement et de recherche français ou étrangers, des laboratoires publics ou privés. 
1 Influence of food on the assimilation of selected metals in tropical bivalves from the

2 New Caledonia lagoon: qualitative and quantitative aspects

3

4 Laetitia Hédouin $^{1-3}$, Marc Metian ${ }^{1-2}$, Thomas Lacoue-Labarthe ${ }^{2}$, Renaud Fichez ${ }^{3 \dagger}$, Paco

5 Bustamante ${ }^{2} \&$ Michel Warnau $^{1 *}$

6

$7{ }^{1}$ International Atomic Energy Agency - Marine Environment Laboratories (IAEA-MEL),

84 Quai Antoine Ier, MC-98000 Principality of Monaco

$9{ }^{2}$ Littoral, Environnement et Sociétés (LIENSS), UMR 6250 CNRS-Université de La

10 Rochelle, 2 rue Olympe de Gouges, F-17042 La Rochelle, France

$11{ }^{3}$ Institut de Recherche pour le Développement (IRD-Nouméa Center), BP A5, 98848

$12 \quad$ Nouméa cedex, New-Caledonia

13

14 *Corresponding author: Michel Warnau

15 Current address: Littoral, Environnement et Sociétés (LIENSs)

16

UMR 6250 CNRS-Université de La Rochelle

17

2 rue Olympe de Gouges, F-17042 La Rochelle (France)

18

E-mail: warnaumichel@yahoo.com

19

Phone: +33662538327

20

$21 \dagger$ Current address: IRD, Universidad Autonoma Metropolitana Iztapalapa, Departamento

22 de Hidrobiología, Col. Vicentina C.P. 09340, Iztapalapa, México D.F. \& Université de la

23 Méditerranée, UMR CNRS 6535 LOPB, F-13007 Marseille, France.

24 


\section{Abstract}

The present study aimed at examining the influence of food quality and quantity on the assimilation efficiency (AE) of metals in two abundant bivalves in the New

29 Caledonia lagoon, the oyster Isognomon isognomon and the clam Gafrarium tumidum.

30 Bivalves were exposed via their food to the radiotracers of three metals of concern in

31 New Caledonia $\left({ }^{54} \mathrm{Mn},{ }^{57} \mathrm{Co}\right.$ and ${ }^{65} \mathrm{Zn}$ ) under different feeding conditions (phytoplankton

32 species, cell density, and cell-associated metal concentration). When bivalves were fed

33 Heterocapsa triquetra, Emiliania huxleyi and Isochrysis galbana, AE of Mn, Co and $\mathrm{Zn}$

34 was strongly influenced by the phytoplankton species and by the metal considered. In

35 contrast, when fed one given phytoplankton species previously exposed to different

36 concentrations of Co, phytoplankton-associated Co load had no influence on the AE and

37 on the retention time of the metal in both bivalves. Metals ingested with I. galbana

38 displayed generally the highest AE in both bivalve species, except for Mn in clams for

39 which the highest $\mathrm{AE}$ was observed for $H$. triquetra. Influence of food quantity was

40 investigated by exposing bivalves to different cell densities of I. galbana $\left(5 \times 10^{3}, 10^{4}\right.$ or

$415 \times 10^{4}$ cell ml $^{-1}$ ). As for food quality, food quantity was found to influence AE of Mn, Co

42 and $\mathrm{Zn}$, the highest $\mathrm{AE}$ being observed when bivalves were fed the lowest cell density.

43 Overall, results indicate that the two bivalve species are able to adjust their feeding

44 strategies according to the food conditions prevailing in their environment.

46 Keywords: Mollusks, Isognomon isognomon, Gafrarium tumidum, New Caledonia, 47 Radiotracer, Feeding 


\section{1. Introduction}

Changes in coastal ecosystem functioning due to anthropogenic metal inputs is a

53 worldwide issue of concern especially as metals are not biodegradable and enter

54 biogeochemical cycles (Tessier and Turner, 1995). In the coral reef lagoon of New-

55 Caledonia, metal contamination is a critical problem in relation with its extreme

56 biodiversity (Labrosse et al., 2000). Indeed, the lagoon is subject to an increasing

57 environmental pressure imposed by urban development and intensive mining activities. In

58 addition, the use of hydrometallurgic process employing heated and pressured sulphuric

59 acid (lixiviation) has been recently developed in New Caledonia and is expected to be

60 implemented at industrial scale early 2010 (Goro-Nickel, 2001, 2003). Such a process

61 will provide new potential to exploit laterite soils that display lower nickel (Ni) contents

62 than garnierite ores currently used in pyrometallurgic plants, such as at the Société Le

63 Nickel, and will allow recovering the cobalt (Co) as a by-product (Mihaylov et al., 2000;

64 Dalvi et al., 2004). However, the $\mathrm{Ni}$ and Co extraction based on lixiviation is an

65 unselective process that may result in additional discharges of by-product metals such as

66 chromiun (Cr), iron (Fe), manganese (Mn) or zinc (Zn) (Goro-Nickel, 2001; Baroudi et

67 al., 2003).

68 Although long lasting contamination exists in New Caledonia (Laganier, 1991;

69 Ambatsian et al., 1997) with high levels of metals reported in coastal marine sediments

70 (e.g. Fernandez et al., 2006), few data on contamination levels in marine organisms and

71 possible local marine ecosystem impairments are available so far in the open literature 
72 (e.g. Monniot et al., 1994; Dalto et al., 2006; Hédouin et al., 2008a,b; Metian and

73 Warnau, 2008; Chouvelon et al., 2009). Therefore, programmes for monitoring possible

74 impact of the land-based mining activities in the New Caledonia lagoon are needed. Such

75 programmes should largely rely on the use of biomonitor species, as already developed

76 and implemented in temperate areas (e.g. US and EU Mussel Watches; see e.g. Goldberg

77 et al., 1983; Warnau and Acuña, 2007; Thébault et al., 2008). Indeed, the main advantage

78 of the biomonitoring approach compared to direct measurement in water or sediment is to

79 provide a direct and time-integrated assessment of the metal fraction that is actually

80 available to the organisms (bioavailable fraction) (e.g., Phillips, 1991; Coteur et al., 2003;

81 Danis et al., 2004; Metian et al., 2008b).

82 In this context, both experimental and field studies have recently identified the

83 oyster Isognomon isognomon and the clam Gafrarium tumidum as promising candidates

84 biomonitoring metal contamination in New Caledonia lagoon waters (Metian et al., 2005;

85 Hédouin et al., 2006, 2007, 2008a; Chouvelon et al., 2009).

It is now well established that food is often a dominant pathway for metal

87 bioaccumulation in marine invertebrates and that food composition and/or quantity can

88 strongly influence metal assimilation efficiency (AE) (e.g., Borchardt, 1983; Riisgard et

89 al., 1987; Wang and Fisher, 1999a). Furthermore, feeding processes such as filtration rate

90 are flexible in marine filter-feeding organisms and may be adapted according to the

91 changes in environmental conditions such as food quantity and/or composition (e.g.,

92 Widdows and Donkin, 1992; Navarro and Iglesias, 1993). For example, Cd assimilation

93 in the mussel Mytilus edulis is inversely related to food quantity (Borchardt, 1983). In the

94 scallop Pecten maximus, food is the main bioaccumulation pathway for $\mathrm{Ag}(\sim 98 \%)$ when 
95 diet is composed of Bacillariophyceae phytoplankton whereas dietary contribution drops

96 below 40\% when the scallop is fed Prymnesiophyceae phytoplankton (Metian et al.,

97 2008a). Furthermore, heterorhabdic bivalves (those which gills are composed of 2

98 different filament types) are also able to select the particles that they are ingesting (Ward

99 et al., 1998), which results in a preferential ingestion of nutritionally-rich particles that

100 may also affect metal influx from food (e.g., Bayne, 1993; Wang and Fisher, 1997).

101 The objective of this study was thus to investigate the possible influence of food

102 quality (i.e. phytoplankton species) and quantity on the assimilation efficiency of three

103 metals of concern in New Caledonia lagoon waters (Co, Mn and $\mathrm{Zn}$ ) in the oyster

104 Isognomon isognomon and the clam Gafrarium tumidum. The variations in the feeding

105 conditions that were considered are: (1) the phytoplankton species used as food, (2) the

106 phytoplankton density and (3) the metal concentration associated with phytoplankton.

107 Radiotracer techniques were used to enhance the detection sensitivity of metals and to

108 allow for measuring metal flux at environmentally realistic contaminant concentrations

109 (Warnau and Bustamante, 2007).

\section{2. Materials and Methods}

\section{2.1. Collection and Acclimation}

The organisms ( $\mathrm{n}=100$ per species) were collected by SCUBA diving in Maa

116 Bay (oysters Isognomon isognomon) or by hand-picking in Dumbea Bay (clams

117 Gafrarium tumidum) in October 2003. Both locations are located 15 to $20 \mathrm{~km}$ north of 
118 Nouméa City, New Caledonia. Body size is known to affect bioaccumulation of metals in 119 marine organisms (e.g., Boyden, 1974; Warnau et al., 1995); hence, according to previous 120 preliminary studies (Metian, 2003; Hédouin et al., 2006, 2008a), only individuals with a 121 shell longer than $70 \mathrm{~mm}$ (I. isognomon) or a shell wider than $35 \mathrm{~mm}$ (G. tumidum) were 122 used in the experiments. After collection, clams and oysters clams were shipped to IAEA123 MEL premises in Monaco, where they were acclimated for 2 months to laboratory 124 conditions (open circuit aquarium; water renewal: $30 \% \mathrm{hr}^{-1}$; salinity: 36 p.s.u.; 125 temperature $\mathrm{T}^{\circ}=25 \pm 0.5^{\circ} \mathrm{C} ; \mathrm{pH}=8.0 \pm 0.1 ;$ light/dark cycle: $12 \mathrm{hrs} / 12 \mathrm{hrs}$ ) simulating 126 the conditions prevailing in the New Caledonia lagoon. During acclimation, bivalves 127 were fed phytoplankton using the Prymnesiophyceae Isochrysis galbana $\left(10^{4}\right.$ cells $\left.\mathrm{ml}^{-1}\right)$. 128 Recorded mortality was lower than $5 \%$ over the acclimation period.

$130 \quad$ 2.2. Radiotracers and Counting Investigated elements ( $\mathrm{Co}, \mathrm{Mn}$ and $\mathrm{Zn})$ were introduced into the experimental 133 microcosms as radiotracers of high specific activity, purchased from Amersham, UK $134\left({ }^{57} \mathrm{Co}\right.$ in $\left.0.1 \mathrm{M} \mathrm{HCl}, \mathrm{T}_{1 / 2}=271.8 \mathrm{~d}\right)$ and Isotope Product Lab., USA $\left({ }^{54} \mathrm{Mn}\right.$ in $0.1 \mathrm{M} \mathrm{HCl}, \mathrm{T}_{1 / 2}$ $135=312.2 \mathrm{~d} ;{ }^{65} \mathrm{Zn}$ in $\left.0.5 \mathrm{M} \mathrm{HCl} ; \mathrm{T}_{1 / 2}=243.9 \mathrm{~d}\right)$.

136 Radioactivity was measured using a high-resolution $\gamma$-spectrometer system 137 composed of three Germanium -N or P type- detectors (EGNC 33-195-R, Eurysis ${ }^{\circledR}$ ) 138 connected to a multi-channel analyzer and a computer equipped with a spectra analysis 139 software (Interwinner ${ }^{\circledR}$ 6). The radioactivity of the samples was determined by 140 comparison with standards of known activities and of appropriate geometry. 
141 Measurements were corrected for counting efficiency, background and physical 142 radioactive decay. Counting times were adapted to obtain counting rates with propagated

143 errors less than 5\% (Rodriguez y Baena et al., 2006a).

\subsection{Experimental Procedures}

147 2.3.1. Testing the influence of Co concentration in food

Isochrysis galbana cells from an axenic stock culture were resuspended into 4

150 erlenmeyer flasks (light/dark cycle: $12 \mathrm{hrs} / 12 \mathrm{hrs}$ at $25^{\circ} \mathrm{C}$ ). Each flask contained $500 \mathrm{ml}$ 151 sterile-filtered seawater enriched with $\mathrm{f} / 2$ nutrients without EDTA and Si (Guillard, 152 1975). Flasks were spiked with 4 increasing Co concentrations $\left(0,5,50,500 \mathrm{ng} \mathrm{l}^{-1}\right)$ and 153 phytoplankton was allowed to grow under these conditions for $6 \mathrm{~d}$. Added Co 154 concentrations were realized using increasing amount of $\mathrm{Co}\left(\mathrm{NO}_{3}\right)_{2}$ (synthesis quality, 155 Merck) and a fixed activity of the corresponding radiotracer ${ }^{57} \mathrm{Co}\left(2.5 \mathrm{kBq} \mathrm{l}^{-1}\right.$, 156 corresponding to $0.13 \mathrm{ng} \mathrm{Co}^{-1}$ ). The range of concentrations selected covers those 157 encountered in the New Caledonia lagoon waters (Fernandez et al., 2002; Goro-Nickel, 158 2004). After $6 \mathrm{~d}$ of incubation, cell density increased from $10^{3}$ to $1.5 \times 10^{6}$ cell ml $^{-1}$. The 159 cells were gently filtered $\left(1 \mu \mathrm{m}\right.$-mesh size, Nuclepore ${ }^{\circledR}$ Polycarbonate filters $)$ and 160 resuspended in clean seawater. The radioactivity of the radiolabelled I. galbana in each 161 flask was $\gamma$-counted before and after the filtration. The radioactivity of algal cells used in 162 feeding experiments was not significantly different among the different flasks, with an 163 average calculated activity of $0.49 \pm 0.14 \mu \mathrm{Bq}$ cell $^{-1}$. 
$165 \mathrm{~mm}$ ) and 4 groups of 9 clams (shell width from 35 to $40 \mathrm{~mm}$ ) were placed in 4 aquaria 166 containing 161 of $0.45-\mu \mathrm{m}$ filtered natural seawater (close circuit aquaria constantly

167 aerated; other parameters as previously described). Oysters were acclimated for one week

168 to these conditions and seawater was renewed daily. Bivalves from each aquarium were

169 then allowed to feed for 2 hrs on one out of the 4 batches of previously radiolabelled

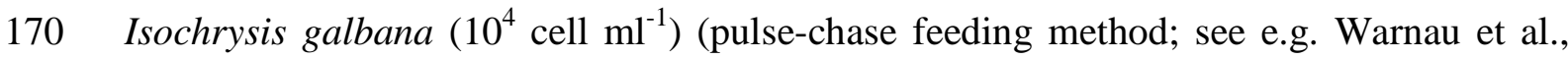
171 1996b).

172 Empty shells were placed as control in each aquarium to check for any direct 173 uptake of radiotracers from seawater due to possible recycling from phytoplankton cells 174 during the 2-hr feeding period (Metian et al., 2007). These control shells were 175 radioanalysed at regular intervals of time.

176 At the end of the feeding period, all organisms were $\gamma$-counted and open circuit 177 conditions were restored (water renewal rate: $30 \% \mathrm{hr}^{-1}$; salinity: 36 p.s.u.; $\mathrm{T}^{\circ}=25 \pm$ $1780.5^{\circ} \mathrm{C} ; \mathrm{pH}=8.0 \pm 0.1 ;$ light $/$ dark cycle: $\left.12 \mathrm{hrs} / 12 \mathrm{hrs}\right)$. From that time on, all individuals 179 were $\gamma$-counted at different time intervals over a 25 -d period in order to determine the 180 whole-body depuration kinetics of the radiotracers ingested with food. Throughout the 181 depuration period, bivalves were fed daily for $1 \mathrm{hr}$ non-radiolabelled phytoplankton 182 (Isochrysis galbana, $10^{4}$ cell $\mathrm{ml}^{-1}$ ).

184 2.3.2. Testing the influence of phytoplankton species 
Two batches of 9 oysters (shell length from 73 to $90 \mathrm{~mm}$ ) and 2 batches of 9

187 clams (shell width from 35 to $44 \mathrm{~mm}$ ) were placed in 2 aquaria containing 161 of 0.45 -

$188 \mu \mathrm{m}$ filtered natural seawater (close circuit aquaria constantly aerated; other parameters as

189 previously described). Clams and oysters were acclimated to these conditions for 1 week

190 (daily seawater renewal) and then fed either radiolabelled Emiliania huxleyi or

191 Heterocapsa triquetra $\left(10^{4}\right.$ cell $\left.\mathrm{ml}^{-1}\right)$ for $2 \mathrm{hrs}$ (pulse-chase feeding) in order to asses the

192 possible influence of the phytoplankton species on metal assimilation efficiency and

193 retention capacity in the bivalves. Both phytoplankton species occur naturally in several

194 bays of the New Caledonia lagoon where the clams and oysters are living (Jacquet et al., 195 2006).

196 For radiolabelling phytoplankton species, experimental approaches conducted on

197 I. galbana were applied to the Prymnesiophyceae E. huxleyi and to the Dinophyceae $H$.

198 triquetra. Cells from axenic stock cultures were re-suspended in two different erlenmeyer

199 flasks $\left(10^{3}\right.$ cell ml $\left.{ }^{-1}\right)$, containing 4.51 sterile-filtered seawater enriched with $\mathrm{f} / 50$ for $E$.

200 huxleyi and enriched with $\mathrm{f} / 2$ nutrients without EDTA and Si for H. triquetra (Guillard,

201 1975). The two cultures were spiked with $5 \mathrm{kBq} \mathrm{l}^{-1}$ of ${ }^{54} \mathrm{Mn},{ }^{57} \mathrm{Co}$ and ${ }^{65} \mathrm{Zn}$,

202 corresponding to $3.6 \mathrm{ng} \mathrm{Mn}^{-1}, 25 \mathrm{ng} \mathrm{Co}^{-1}$ and $60 \mathrm{ng} \mathrm{Zn}^{-1}$. The cultures were then

203 incubated for $6 \mathrm{~d}$ at $25^{\circ} \mathrm{C}$ (light/dark cycle: $12 \mathrm{hrs} / 12 \mathrm{hrs}$ ). After incubation, the cell

204 densities were $7 \times 10^{5}$ cell $\mathrm{ml}^{-1}$ for E. huxleyi and $1.6 \times 10^{5} \mathrm{cell} \mathrm{ml}^{-1}$ for $H$. triquetra. The

205 cells were then gently filtered, resuspended in clean seawater and $\gamma$-counted as described

206 above (section 2.3.1.). The radioactivity of algal cells used in the feeding experiments

207 was $0.26 \pm 0.18 \mu \mathrm{Bq}$ cell $^{-1}$ for $E$. huxleyi and $0.96 \pm 0.11 \mu \mathrm{Bq}$ cell $^{-1}$ for $H$. triquetra for 
${ }^{54} \mathrm{Mn}, 2.1 \pm 0.8$ and $20.8 \pm 12.1 \mu \mathrm{Bq}$ cell $^{-1}$ for ${ }^{57} \mathrm{Co}$ and $3.2 \pm 1.3$ and $3.3 \pm 0.1 \mu \mathrm{Bq}$ cell $^{-1}$

209 for ${ }^{65} \mathrm{Zn}$, respectively.

210 Empty bivalve shells were used as controls for possible metal recycling and

211 whole-body depuration kinetics of radiotracer ingested with the food were determined in

212 both bivalve species as described in section 2.3.1.

214 2.3.3. Testing the influence of cellular density

Three groups of 9 oysters (shell length from 71 to $92 \mathrm{~mm}$ ) and 3 groups of 9

217 clams (shell width from 36 to $45 \mathrm{~mm}$ ) were placed in 3 aquaria containing 161 of 0.45 -

$218 \mu \mathrm{m}$ filtered natural seawater (close circuit aquaria constantly aerated; other parameters as

219 previously described), and acclimated for one week (daily seawater renewal) during 220 which time their food was prepared.

221 To do this, cells of I. galbana from an axenic stock culture were resuspended in an 222 erlenmeyer flask containing 4.51 sterile-filtered seawater enriched with $\mathrm{f} / 2$ nutrients 223 without EDTA and Si. The culture was then spiked with $5 \mathrm{kBq}^{-1}$ of ${ }^{54} \mathrm{Mn},{ }^{57} \mathrm{Co}$ and ${ }^{65} \mathrm{Zn}$ 224 and incubated for $6 \mathrm{~d}$ at $25^{\circ} \mathrm{C}$ (light/dark cycle: $12 \mathrm{hrs} / 12 \mathrm{hrs}$ ). After incubation, the cell 225 density had increased from $10^{3}$ to $1.4 \times 10^{6}$ cell ml$^{-1}$. Three sub-samples of 58,115 and $226580 \mathrm{ml}$ of the culture were then gently filtered and resuspended in clean seawater. These 2273 batches were prepared to obtain final cell density of $5 \times 10^{3}, 10^{4}$ and $5 \times 10^{4}$ cell ml $^{-1}$ in 228 the 16-1 exposure aquaria. The radioactivity of the radiolabelled I. galbana was measured 229 before and after the cellular filtration. The radioactivity of algal cells ranged from 1.11 to $230 \quad 1.80 \mu \mathrm{Bq}$ cell ${ }^{-1}$ for ${ }^{54} \mathrm{Mn}, 0.83$ to $1.37 \mu \mathrm{Bq}_{\text {cell }}{ }^{-1}$ for ${ }^{57} \mathrm{Co}, 2.69$ to $4.38 \mu \mathrm{Bq} \mathrm{cell}^{-1}$ for ${ }^{65} \mathrm{Zn}$. 
232 galbana batches $\left(5 \times 10^{3}, 10^{4}\right.$ or $5 \times 10^{4}$ cell $\left.\mathrm{ml}^{-1}\right)$. Whole-body depuration kinetics of the

233 radiotracers ingested with the food were then followed as described in section 2.3.1 and

234 controls (empty shells) were placed in the aquaria for assessing possible radiotracer 235 recycling.

\subsection{Data Analysis}

Depuration of the radiotracers was expressed as the percentage of remaining

240 radioactivity (radioactivity at time $t$ divided by initial radioactivity measured in the 241 organisms just after the feeding period * 100) (Warnau et al., 1996b; Rodriguez y Baena 242 et al., 2006b).

243 Depuration kinetics for all experiments were fitted using kinetic models and 244 statistical methods as described by Warnau et al. (1996a,b) and Lacoue-Labarthe et al. 245 (2008). Depuration kinetics were always best fitted by a double-component exponential 246 equation (decision based on $\mathrm{F}$ test and ANOVA tables for two fitted model objects):

$247 \quad \mathrm{~A}_{\mathrm{t}}=\mathrm{A}_{0 \mathrm{~s}} \mathrm{e}^{-\mathrm{k}_{\mathrm{es}} t}+\mathrm{A}_{01} \mathrm{e}^{-\mathrm{k}_{\mathrm{el}} t}$

248 where $\mathrm{k}_{\mathrm{e}}$ is the depuration rate constant $\left(\mathrm{d}^{-1}\right), \mathrm{A}_{\mathrm{t}}$ and $\mathrm{A}_{0}$ are the remaining activities $(\%)$ at 249 time $t(\mathrm{~d})$ and 0 , respectively, and ' $\mathrm{s}$ ' and ' $\mathrm{l}$ ' are the subscripts for the short-lived and 250 long-lived components. The short-lived component represents the loss of the radiotracer 251 fraction that remains associated with the faeces and is rapidly eliminated with them, 252 whereas the long-lived component describes the loss of the radiotracer fraction that is 253 actually absorbed by the organism and slowly eliminated (Whicker and Schultz, 1982; 
254 Warnau et al., 1996b). The long-lived component allows assessing the assimilation 255 efficiency $(\mathrm{AE})$ of the radiotracer ingested with food $\left(\mathrm{AE}=\mathrm{A}_{01}\right)$. Also, for each 256 exponential component ( $\mathrm{s}$ and 1 ), a biological half-life can be calculated $\left(\mathrm{T}_{\mathrm{b}^{1 / 2 \mathrm{~s}}}\right.$ and $\left.\mathrm{T}_{\mathrm{b}^{1 / 21}}\right)$

257 from the corresponding depuration rate constant $\left(\mathrm{k}_{\mathrm{es}}\right.$ and $\left.\mathrm{k}_{\mathrm{el}}\right)$ according to the relation $\mathrm{T}_{\mathrm{b} / 2}$ $258=\ln 2 / \mathrm{k}_{\mathrm{e}}$.

259 Constants of the models and their statistics were estimated by iterative 260 adjustments of the model and Hessian matrix computation using the nonlinear curve261 fitting routines in the Statistica ${ }^{\circledR}$ 5.2.1 software. Differences among the estimated kinetic 262 parameters for the different feeding conditions were tested using comparison tests of the 263 means and possible trends linking metal concentrations to cell densities were assessed 264 using simple linear regression techniques (Zar, 1996). The level of significance for 265 statistical analyses was always set at $\alpha=0.05$.

\section{3. Results}

269 Depuration kinetics of the radiotracers were followed in the organisms which 270 ingested enough food to display sufficient radioactivity to be accurately counted. Most 271 oysters met this requirement; however some clams displaying very low activities were 272 discarded. No activity was detected on control shells, indicating that no detectable 273 recycling of phytoplankton-associated tracers occurred in the experimental microcosms.

\subsection{Effect of Co Concentration in Phytoplankton}


278 galbana by a double-exponential model was quite satisfactory $\left(\mathrm{R}^{2}: 0.86-0.90\right)$ for all the

279 food-associated Co concentrations tested (Table 1, Fig. 1). The major fraction (80-85\%)

280 of the total radioactivity in oysters was rapidly lost $\left(\mathrm{T}_{\mathrm{b}^{1 / 2 \mathrm{~S}}}<1 \mathrm{~d}\right)$ whereas the long-lived

281 component accounted for only $15-20 \%$ of the ${ }^{57}$ Co ingested with food that was eliminated

282 with a biological half life $\left(\mathrm{T}_{\mathrm{b}^{1 / 2}}\right)$ ranging from 13 to $25 \mathrm{~d}$.

283 Similarly, the fit of the whole-body depuration of ${ }^{57} \mathrm{Co}$ in clams was quite good

284 ( $\mathrm{R}^{2}$ : 0.27-0.64) for all the Co concentrations tested (Table 1, Fig. 1). However, the 285 estimated $\mathrm{AE}$ of ${ }^{57} \mathrm{Co}$ ingested with food was much higher than in oysters (i.e., 76-84\%) 286 and this fraction was retained with a $\mathrm{T}_{\mathrm{b}^{1 / 2}}$ ranging from 36 to $39 \mathrm{~d}$.

287 In both bivalve species, no significant difference ( $\mathrm{p}$ always $>0.05$ ) was found 288 among the estimated kinetic parameters $\left(\mathrm{A}_{\mathrm{os}}, \mathrm{k}_{\mathrm{es}}, \mathrm{A}_{\mathrm{ol}}, \mathrm{k}_{\mathrm{el}}\right)$ determined for the 4 different 289 food-associated Co concentrations.

\subsection{Effect of Phytoplankton Species}

In oysters, depuration kinetics of ${ }^{54} \mathrm{Mn},{ }^{57} \mathrm{Co}$ and ${ }^{65} \mathrm{Zn}$ ingested with I. galbana

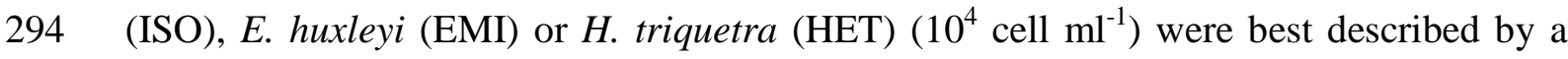
295 double-exponential model ( $\mathrm{R}^{2}$ : 0.23- 0.63 for ISO, 0.11-0.83 for EMI and 0.57-0.92 for 296 HET) (Table 2, Fig. 2). No significant difference was found among estimated $\mathrm{T}_{\mathrm{b}^{1 / 2}}$ for all 297 radiotracers and all phytoplankton species tested. In addition, no significant difference 298 was found between AEs for Co and Mn in oysters fed EMI and HET, and for $\mathrm{Zn}$ in 299 oysters fed ISO and EMI. In contrast, significant differences $(\mathrm{p}<0.02)$ among AEs were 
300 observed for Co and Mn (ISO > HET = EMI, p < 0.004) and fro Zn (ISO = EMI > HET, $301 \mathrm{p}<0.02)$.

302 In clams, fitting of the whole-body depuration of the radiotracers ingested with $I$. 303 galbana, E. huxleyi or H. triquetra $\left(10^{4}\right.$ cell $\left.\mathrm{ml}^{-1}\right)$ were genrally somewhat better than in 304 the oyster ( $\mathrm{R}^{2}:$ : $0.47-0.98$ for ISO, $0.47-0.93$ for EMI and 0.61-0.89 for HET) (Table 2, 305 Fig. 2). $\mathrm{T}_{\mathrm{b} / 2}$ of ${ }^{54} \mathrm{Mn}$ was significantly longer when it was assimilated from HET than 306 from EMI or ISO ( $p=0.03$ and 0.004 , respectively). Significant differences were also 307 observed among AEs calculated for $\mathrm{Co}, \mathrm{Mn}$ and $\mathrm{Zn}$ ingested with the three phytoplankton 308 strains $(\mathrm{Mn}$ : ISO < EMI = HET, $\mathrm{p}<0.03$; Co: $\mathrm{ISO}=\mathrm{EMI}>\mathrm{HET}, \mathrm{p}<0.0004$; and Zn: $309 \quad$ ISO $\geq$ EMI $\geq$ HET, $p=0.04)$.

313 When oysters were fed $10^{4}$ and $5 \times 10^{4}$ cells $\mathrm{ml}^{-1}$ of radiolabelled I. galbana, 314 whole-body depuration kinetics of ${ }^{54} \mathrm{Mn},{ }^{57} \mathrm{Co}$ and ${ }^{65} \mathrm{Zn}$ were fitted with $\mathrm{R}^{2}$ ranging from 3150.23 to 0.63 and 0.38 to 0.60 , respectively (Table 2, Fig. 3). No significant difference in $316 \mathrm{~T}_{\mathrm{b}^{1 / 2}}$ and $\mathrm{AE}$ between cell densities was found for Co. In contrast, significant differences 317 in $\mathrm{AE}$ were found for $\mathrm{Mn}$ and $\mathrm{Zn}$, with higher $\mathrm{AE}$ calculated at the low cell density $(\mathrm{p}=$ 3180.001 and 0.0003 , respectively).

319 For clams, examination depuration kinetics of the radiotracers $\left(\mathrm{R}^{2}: 0.33-0.65\right.$ at 5 $320 \times 10^{3}$ cell ml${ }^{-1}$ and $0.47-0.98$ at $10^{4}$ cell ml $^{-1}$ ) indicated that $\mathrm{T}_{\mathrm{b}^{1 / 2}}$ was not significantly 321 different between the two food densities for all three radiotracers (Table 2, Fig. 3). 
322 However, when fed the low cell density, clams incorporated $\mathrm{Co}$, Mn and $\mathrm{Zn}$ with 323 significantly higher $\mathrm{AE}(\mathrm{p}=0.003,0.047$ and 0.0003 , respectively).

\section{4. Discussion} a major source of contaminant accumulation in marine invertebrates (e.g. Wang et al.,

329 1996; Reinfelder et al., 1998; Wang and Fisher, 1999b). The assimilation efficiency (AE)

330 and retention time $\left(\mathrm{T}_{\mathrm{b}^{1 / 2}}\right)$ are the critical parameters in assessing and modelling the dietary 331 uptake of contaminants and numerous studies have been devoted to assess these 332 parameters in different marine organisms (e.g., Wang et al., 1996; Warnau et al., 1996b, 333 1999; Pan and Wang, 2008). However, as almost a rule in tropical environments (e.g., 334 Phillips, 1991; Chong and Wang, 2000; Metian et al., 2005), only very few data are yet 335 available regarding $\mathrm{AE}$ and $\mathrm{T}_{\mathrm{b} / 2}$ parameters for organisms from New Caledonia (e.g. 336 Hédouin et al., 2006, 2007).

337 Ideally, the concentrations of metals in the tissues of a biomonitor species should 338 reflect those occurring in the ambient environment. This essential criterion has been 339 previously experimentally assessed for I. isognomon and G. tumidum for the dissolved 340 pathway (Hédouin et al., 2007, this issue). Exposures to a range of dissolved 341 concentrations of $\mathrm{As}, \mathrm{Cr}, \mathrm{Co}, \mathrm{Cd}, \mathrm{Mn}, \mathrm{Ni}$ and $\mathrm{Zn}$ indicated that, over a realistic range of 342 concentrations, these elements were generally bioconcentrated in direct proportion to 343 their concentration in seawater (ibid.). The results presented here are complementary with 
344 these previous studies as they expand the available knowledge regarding metal

345 accumulation in I. isognomon and G. tumidum to the dietary pathway.

346 When ingested with phytoplankton previously exposed to a range of increasing

347 Co concentration (up to $500 \mathrm{ng}$ added $\mathrm{Co}^{-1}$ ) Co was shown to be assimilated in the same

348 proportion $(\mathrm{AE})$ and retained with similar relative strength $\left(\mathrm{T}_{\mathrm{b}^{1 / 2}}\right)$ whatever the food-

349 associated Co concentration was (see Fig.1 and Table1). The experimental conditions

350 were designed to cover the whole range of Co concentrations that can be encountered in

351 New Caledonia waters, from pristine up to extremely contaminated areas (Fernandez et

352 al., 2002; Goro-Nickel, 2004). Similar trends have been previously reported by Chong

353 and Wang (2000) who observed that concentration of $\mathrm{Cd}, \mathrm{Cr}$ and $\mathrm{Zn}$ in sediment had little

354 effect on the assimilation efficiency of sediment-bound metals in the green mussel Perna

355 viridis and in the Manila clam Ruditapes philippinarum. However, the response to metal

356 concentration variation in ingested food appears to depend on the element as well as on

357 the species investigated. Indeed, whereas AE of Se in the mussel Mytilus edulis was not

358 affected by the Se concentration in the ingested diatoms (Thalassiosira pseudonana), AE

359 of $\mathrm{Zn}$ and $\mathrm{Cd}$ did respectively decrease and increased with increasing contamination of

360 the diatom used as food (Wang and Fisher, 1996). Nevertheless, along with data obtained

361 from exposures to increasing dissolved Co concentrations in the same species (Hédouin

362 et al., this issue), the present results on Co AE indicate that in the field Co concentrations

363 in both I. isognomon and G. tumidum would be reflecting the level of Co in their

364 environment, both in the dissolved and particulate phases.

365 Whereas food quality and quantity were shown to have limited influence on the

366 retention time of $\mathrm{Co}, \mathrm{Mn}$ and $\mathrm{Zn}$ in clam and oyster tissues, metal AE generally differed 
367 according to the feeding conditions. Metals were generally better assimilated when 368 bivalves were fed I. galbana than the two other phytoplankton species (E. huxleyi or H. 369 triquetra). I. galbana cells have comparable cell length (c.1.: 4-6 $\mu \mathrm{m})$ and cell width 370 (c.w.: 2-4 $\mu \mathrm{m}$ ) than E. huxleyi cells (c.1.: 3-4 $\mu \mathrm{m}$; c.w.: 3-4 $\mu \mathrm{m}$ ), but are much smaller 371 than $H$. triquetra cells (c.1.: 20-28 $\mu$ m; c.w.: 14-18 $\mu \mathrm{m}$ ). Hence, the differences and 372 similarities in AE observed among the feeding conditions indicate that phytoplankton size 373 would not be the major factor driving metal AEs in the two bivalves. Bivalves are able to 374 feed selectively on particles of different size and of different nature (various 375 phytoplankton species as well as inorganic particles) (e.g., Newell et al., 1989) and 376 species-related selectivity and/or dietary preferences could at least partly explain the 377 specific differences observed in AE. Alternatively or complementarily, specific 378 difference in metal speciation such as storage of the metal under bioavailable forms in the 379 cytoplasm of the phytoplankton cells (e.g., Reinfelder and Fisher, 1991; Wang et al., 380 1996; Metian et al., 2008a) could also explain the AE differences that were observed.

381 Food availability is another key factor that is well known to influence feeding 382 behaviour of filter-feeding bivalves (e.g. Bayne et al., 1987; Bayne, 1993; Pan and Wang, 383 2008). Generally, filter-feeders can adjust their filtration rate to ambient phytoplankton 384 density and thereby are able to maintain a stable ingestion rate even at high food 385 concentrations (Jin et al., 1996; Dong et al., 2000; Zhuang and Wang, 2004). Although no 386 conclusion on the influence of this adaptive feeding behaviour could be directly drawn 387 from our results, it is clear that food availability notably influenced the AE of the metals 388 examined in I. isognomon and G. tumidum. 
It is nowadays well documented that the dietary pathway is an important

390 contributor to the global bioaccumulation of metals in marine organisms (e.g. Wang and

391 Fisher, 1997; Metian et al., 2008a). Since the present study has shown that the feeding

392 behaviour of I. isognomon and G. tumidum is influenced by the feeding conditions

393 (quality and/or quantity of food), it is strongly recommended that future studies take into

394 account these parameters so as to refine the prediction of biodynamic models (e.g.,

395 Thomann et al., 1995; Metian et al, 2008a; Pan and Wang, 2008). The consideration of

396 such data is also needed to explain bioaccumulation data obtained in the framework of

397 biomonitoring programmes. For example, Bendell-Young and Arifin (2004)

398 demonstrated the influence of mussel feeding behaviour on their predicted tissue

399 concentrations in Cd, especially under conditions of highly variable quantity and quality

400 of suspended particles.

401 In conclusion, our experimental results suggest that food quality (phytoplankton 402 composition) and quantity (cell density) may play a significant role in the assimilation of 403 metals ingested with food in I. isognomon and G. tumidum. Because of the major 404 importance of the dietary contribution to global metal bioaccumulation in marine 405 organisms, it is thus recommended to pay great attention to factors influencing AE. This 406 would help refining both bioaccumulation model predictions and interpretation of data 407 from field surveys and biomonitoring programmes.

\section{5. Acknowledgements}


The authors thank J.L. Teyssié (IAEA-MEL) for valuable technical advices and

412 O. Pringault (IRD-Nouméa) for critical reading of the manuscript. LH was beneficiary of

413 a PhD grant (CIFRE, France) supported by the Goro-Nickel Company, New Caledonia.

414 MW is an Honorary Senior Research Associate of the National Fund for Scientific

415 Research (NFSR, Belgium) and holds a 2008-09 Invited Expert position at LIENSs

416 (CNRS-Université de La Rochelle), supported by the Conseil Régional de Poitou-

417 Charentes. This work was supported by the IAEA, the French PNEC Programme

418 (Chantier "Nouvelle-Calédonie") and IRD. The IAEA is grateful for the support provided

419 to its Marine Environment Laboratories by the Government of Monaco.

\section{$421 \quad$ 6. References}

423 Ambatsian, P., Fernex, F., Bernat, M., Parron, C., Lecolle, J., 1997. High metal inputs to closed seas: the New Caledonia lagoon. Journal of Geochemical Exploration 59, $59-74$.

426 Baroudi, H., Bureau, J., Rollin, C., 2003. Analyse critique de l'acceptabilité du niveau de rejet de manganèse dans le milieu marin, Rapport final Goro-Nickel INERIS Institut National de l'Environnement Industriel et des Risques, 37 p. (In French).

429 Bayne, B.L., 1993. Feeding physiology of bivalves: time-dependence and compensation for changes in food availability. In: Dame, R.F. (Ed.), Bivalve filter feeders in estuarine and coastal ecosystem processes. Springer-Verlag, Heidelberg, pp. 1-24. 
Bayne, B.L., Hawkins, A.J.S., Navarro, E., 1987. Feeding and digestion by the mussel Mytilus edulis L. (Bivalvia: Mollusca) in mixtures of silt and algal cells at low concentration. Journal of Experimental Marine Biology and Ecology 111, 1-22.

Bendell-Young, L.I., Arifin, Z., 2004. Application of a kinetic model to demonstrate how selective feeding could alter the amount of cadmium accumulated by the blue mussel (Mytilus trossolus). Journal of Experimental Marine Biology and Ecology 298, 21-33.

Borchardt, T., 1983. Influence of food quantity on the kinetics of cadmium uptake and loss via food and seawater in Mytilus edulis. Marine biology 79, 67-76.

Boyden, C.R., 1974. Trace elements contents and body size in molluscs. Nature 251, 311314.

Chong, K., Wang, W.-X., 2000. Bioavailability of sediment-bound Cd, Cr and Zn to the green mussel Perna viridis and the Manila clam Ruditapes philippinarum. Journal of Experimental Marine Biology and Ecology 255, 75-92.

Chouvelon, T., Warnau, M., Churlaud, C., Bustamante, P., 2009. Hg concentrations and related risk assessment in coral reef crustaceans, molluscs and fish from New Caledonia. Environmental Pollution 157, 331-340.

Coteur, G., Gosselin, P., Wantier, P., Chambost-Manciet, Y., Danis, B., Pernet, P., Warnau, M., Dubois, P., 2003. Echinoderms as bioindicators, bioassays, and impact assessment tools of sediment-associated metals and PCBs in the North Sea. Archives of Environmental Contamination and Toxicology 45, 190-202. 
Dalto, A.G., Grémare, A., Dinet, A., Fichet, D., 2006. Muddy-bottom meiofauna responses to metal concentrations and organic enrichment in New Caledonia South-West Lagoon. Estuarine, Coastal and Shelf Science 64, 629-644.

Dalvi, A.D., Bacon, W.G., Osborne, R.C., 2004. The past and the future of nickel laterites, PDAC 2004 International Convention, Trade Show \& Investors Exchange, $27 \mathrm{p}$.

Danis, B., Wantier, P., Dutrieux, S., Flammang, R., Dubois, P., Warnau, M., 2004. Contaminant levels in sediments and asteroids (Asterias rubens L., Echinodermata) from the Belgian coast and Scheldt estuary: polychlorinated biphenyls and heavy metals. Science of the Total Environment 333, 149-165.

Dong, B., Xue, Q.Z., Li, J., 2000. Environmental factors affecting the feeding physiological ecology of Manila clam, Ruditapes philippinarum. Oceanologia et Limnologia Sinica 31, 636-642.

Fernandez, J.M., Breau, L., Cabon, M., Fichez, R., McCorist, G., Magand, O., Moreton, B., Peck, G.A., Szymczak, R., 2002. The fate of metals in New Caledonia. Programme National des Ecosystèmes Côtiers, Banyuls, France.

Fernandez, J.M., Ouillon, S., Chevillon, C., Douillet, P., Fichez, R., LeGendre, R., 2006. A combined modelling and geochemical study of the fate of terrigenous inputs from mixed natural and mining sources in a coral reef lagoon (New Caledonia). Marine Pollution Bulletin 52, 320-331.

Goldberg, E.D., Koide, M., Hodge, V., Flegal, A.R., Martin, J.H., 1983. U.S. Mussel Watch: 1977-1978 results on trace metals and radionuclides. Estuarine, Coastal and Shelf Science 16, 69-93. 
Goro-Nickel, 2001. Projet Goro Nickel. Evaluation environnementale, 52 p. (In French).

477 Goro-Nickel, 2003. Annexe 5.1 Goro Nickel SA - "Rapport de synthèse sur l'impact du rejet en mer de l'effluent" - 1 mars 2004, Document $N^{\circ}$ 47910-000-30R-GEH40002, 36 p. (In French).

Goro-Nickel, 2004. Annexe 2.1 IRD, « Rapport intermédiaire - Caractéristiques physicochimiques des eaux »- mars 2004, 16 p. (In French).

482 Guillard, R.R.L., 1975. Culture of phytoplankton for feeding marine invertebrates. In: Smith, W.L., Charley, M.M. (Eds.), Culture of marine invertebrate animals. Springer, Plenum, New York, pp. 29-60.

Hédouin, L., Bustamante, P., Churlaud, C., Pringault, O., Fichez, R., Warnau, M., 2008a. Trends in concentrations of selected metalloid and metals in two bivalves from the coral reefs in the SW lagoon of New Caledonia. Ecotoxicology and Environmental Safety 72, 372-381.

Hédouin, L., Bustamante, P., Fichez, R., Warnau, M., 2008b. The tropical brown alga Lobophora variegata as a bioindicator of mining contamination in the New Caledonia lagoon: a field transplantation study. Marine Environmental Research $66,438-444$.

493 Hédouin, L., Gomez Batista, M., Metian, M., Buschiazzo, E., Warnau, M., this issue. Metal and metalloid bioconcentration capacity of two tropical bivalves for monitoring the impact of land-based mining activities in the New Caledonia

497 Hédouin, L., Metian, M., Teyssié, J.L., Fowler, S.W., Fichez, R., Warnau, M., 2006. 498 Allometric relationships in the bioconcentration of heavy metals by the edible 

163.

501 Hédouin, L., Pringault, O., Metian, M., Bustamante, P., Warnau, M., 2007. Nickel bioaccumulation in bivalves from the New Caledonia lagoon: seawater and food exposure. Chemosphere 66, 1449-1457.

504 Jacquet, S., Delesalle, B., Torréton, J.P., Blanchot, J., 2006. Response of phytoplankton communities to increased anthropogenic influences (southwestern lagoon, New

Jin, L., Barry, S.P., Shiao, Y.W., 1996. Filtration dynamics of the zebra mussel Dreissena polymorpha. Canadian Journal of Fisheries and Aquatic Sciences 53, 29-37.

509 Labrosse, P., Fichez, R., Farman, R., Adams, T., 2000. New Caledonia. In: Sheppard, C.R.C. (Ed.), Seas at the Millenium: An environmental evaluation. Pergamon, Amsterdam, pp. 723-736.

512 Lacoue-Labarthe, T., Oberhänsli, F.R., Teyssié, J.L., Warnau, M., Koueta, N., 513 Bustamante, P., 2008. Differential bioaccumulation behaviour of two toxic metals 514 (Ag and $\mathrm{Cd}$ ) during the early development of the cuttlefish Sepia officinalis. $515 \quad$ Aquatic Toxicology 86, 437-446.

516 Laganier, R., 1991. Erosion, transport and sedimentation processes associated with opencast mining in New Caledonia: interactions with weather and climate. In: ORSTOM (ed) South Pacific environments: interactions with weather and

520 Metian, M., 2003. Bioaccumulation des métaux lourds chez 4 espèces marines du lagon de Nouvelle Calédonie: Caractérisation de leur potentiel bioindicateur pour le 
monitoring des activités minières locales, Master Thesis, IAEA-MEL, Monaco / Université Libre de Bruxelles, Belgium, 44 p. (In French).

524 Metian, M., Bustamante, P., Cosson, R.P., Hédouin, L., Warnau, M., 2008a. Investigation of $\mathrm{Ag}$ in the king scallop Pecten maximus using field and laboratory approaches. Journal of Experimental Marine Biology and Ecology 367, 53-60.

527 Metian, M., Giron, E., Borne, V., Hédouin, L., Teyssié, J.L., Warnau, M., 2008b. The brown alga Lobophora variegata, a bioindicator species for surveying metal contamination in tropical marine environments. Journal of Experimental Marine Biology and Ecology 362, 49-54.

Metian, M., Hédouin, L., Barbot, C., Teyssié, J.L., Fowler, S.W., Goudard, F., Bustamante, P., Durand, J.-P., Piéri, J., Warnau, M., 2005. Use of radiotracer

536 Metian, M., Warnau, M., 2008. The tropical brown alga Lobophora variegata techniques to study subcellular distribution of metals and radionuclides in bivalves from the Noumea Lagoon, New Caledonia. Bulletin of Environmental Contamination and Toxicology 75, 89-93.

540 Metian, M., Warnau, M., Oberhänsli, F., Teyssié, J.L., Bustamante, P., 2007. 541 Interspecific comparison of Cd bioaccumulation in European Pectinidae (Chlamys 542 varia and Pecten maximus). Journal of Experimental Marine Biology and Ecology $543 \quad 353,58-67$. 
544 Mihaylov, I., Krause, E., Colton, D.F., Okita, Y., Duterque, J.-P., Perraud, J.-J., 2000. The development of a novel hydrometallurgical process for nickel and cobalt recovery from Goro laterite ore. Canadian Mining and Metallurgical Bulletin (Canada) 93, 124-130.

Monniot, F., Martoja, R., Monniot, C., 1994. Cellular sites of iron and nickel accumulation in ascidians related to the naturally and anthropic enriched New Caledonian environment. Annales de l'Institut Océanographique 70, 205-216.

551 Navarro, E., Iglesias, J.I.P., 1993. Infaunal filter-feeding bivalves and the physiological response to short-term fluctuations in food availability and composition. In: Dame, R.F. (Ed.), Bivalve filter feeders in estuarine and coastal ecosystem processes. Springer-Verlag, Berlin, pp. 25-56.

Newell, C.R., Shumway, S.E., Cucci, T.L., Selvin, R., 1989. The effects of natural seston particle size and type on feeding rates, feeding selectivity and food resource availability for the mussel Mytilus edulis Linnaeus at bottom culture sites in Maine. Journal of Shellfish Research 8, 187-196.

Pan, K.E., Wang, W.X., 2008. Validation of biokinetic model of metals in the scallop Chlamys nobilis in complex field environments. Environmental Science and Technology 42, 6285-6290.

Phillips, D.J.H., 1991. Selected trace elements and the use of biomonitors in subtropical and tropical marine ecosystems. Reviews of Environmental Contamination and Toxicology 120, 105-128.

Reinfelder, J.R., Fisher, N.S., 1991. The assimilation of elements ingested by marine copepods. Science 251, 794-796. 
Reinfelder, J.R., Fisher, N.S., Luoma, S.N., Nichols, J.W., Wang, W.-X., 1998. Trace element trophic transfer in aquatic organisms: a critique of the kinetic model approach. Science of the Total Environment 219, 117-135.

Riisgard, H.U., Bjornestad, E., Mohlenberg, F., 1987. Accumulation of cadmium in the mussel Mytilus edulis: kinetics and importance of uptake via food and seawater. Marine Biology 96, 349-353.

Rodriguez y Baena, A.M., Miquel, J.C., Masqué, P., Povinec, P., La Rosa, J., 2006a. A single vs. double spike approach to improve the accuracy of ${ }^{234} \mathrm{Th}$ measurements in small-volume seawater samples. Marine Chemistry 100, 269-281.

Rodriguez y Baena, A.M., Metian, M., Teyssié, J.L., De Broyer, C., Warnau, M., 2006b. Experimental evidence for ${ }^{234} \mathrm{Th}$ bioaccumulation in three Antarctic crustaceans: potential implications in particle flux studies. Marine Chemistry 100, 354-365.

Tessier, A., Turner, D.R., 1995. Metal speciation and bioavailability in aquatic systems. Tessier, A., Turner, D.R. (Eds.), IUPAC Series on Analytical and Physical Chemistry of Environmental Systems, John Wiley \& Sons, Chichester, UK, 696 p.

Thébault, H., Rodriguez y Baena, A.M., Andral, B., Barisic, D., Albaladejo, J.B., Bologa, A.S., Boudjenoun, R., Delfanti, R., Egorov, V.N., El Khoukhi, T., Florou, H., Kniewald, G., Noureddine, A., Patrascu, V., Pham, M.K., Scarpato, A., Stokozov, N.A., Topcuoglu, S., Warnau, M., 2008. ${ }^{137}$ Cs baseline levels in the Mediterranean and Black Sea: a cross-basin survey of the CIESM Mediterranean Mussel Watch Programme. Marine Pollution Bulletin 57, 801-806. 
589 Thomann, R.V., Mahony, J.D., Mueller, R., 1995. Steady-state model of biota sediment accumulation factor for metals in two marine bivalves. Environmental Toxicology and Chemistry 14, 1989-1998.

592 Wang, W.-X., Fisher, N.S., 1996. Assimilation of trace elements by the mussel Mytilus edulis: effects of diatom chemical composition. Marine Biology 125, 715-724.

594 Wang, W.-X., Fisher, N.S., 1997. Modeling metal bioavailability for marine mussels. Reviews of Environmental Contamination and Toxicology 151, 39-65.

596 Wang, W.-X., Fisher, N.S., 1999a. Assimilation efficiencies of chemical contaminants in aquatic invertebrates: a synthesis. Environmental Toxicology and Chemistry 18, 2034-2045.

Wang, W.-X., Fisher, N.S., 1999b. Delineating metal accumulation pathways for marine invertebrates. Science of the Total Environment 237/238, 459-472.

Wang, W.-X., Fisher, N.S., Luoma, S.N., 1996. Kinetic determinations of trace element 602 bioaccumulation in the mussel Mytilus edulis. Marine Ecology Progress Series 140, 91-113.

604 Ward, J.E., Levinton, J.S., Shumway, S.E., Cucci, T., 1998. Particle sorting in bivalves: in vivo determination of the pallial organs of selection. Marine Biology 131, 283-

607 Warnau, M., Acuña, O., 2007. Is there a need for developing an integrated basin-wide monitoring network to enhance sustainable development in the Mediterranean Sea? Rapport de la Commission internationale de la Mer Méditerranée 38, 42 p. ecotoxicological studies. Environmental Bioindicators 2, 217-218. 
612 Warnau, M., Ledent, G., Temara, A., 1995. Allometry of heavy metal bioconcentration in the echinoid Paracentrotus lividus. Archives of Environmental Contamination and Toxicology 29, 393-399.

615 Warnau, M., Fowler, S.W., Teyssie, J.L., 1996a. Biokinetics of selected heavy metals and radionuclides in two marine macrophytes: the seagrass Posidonia oceanica and the alga Caulerpa taxifolia. Marine Environmental Research 41, 343-362.

Widdows, J., Donkin, P., 1992. Mussels and environmental contaminants:

Warnau, M., Teyssié, J.L., Fowler, S.W., 1996b. Biokinetics of selected heavy metals and radionuclides in the common Mediterranean echinoid Paracentrotus lividus: seawater and food exposure. Marine Ecology Progress Series 141, 83-94.

Warnau, M., Teyssié, J.L., Fowler, S.W., 1999. Biokinetics of radiocobalt in the asteroid Asterias rubens (echinodermata): sea water and food exposures. Marine Pollution Bulletin 39, 159-164.

Whicker, F.W., Schultz, V., 1982. Radioecology: nuclear energy and the environment. Schultz, V. (Ed.), CRC Press, Boca Raton, Florida, USA, 320 p.

630 Zar, J.H., 1996. Biostatistical analysis. Prentice-Hall (Ed.), 3rd, Upper Saddle River, New 631 Jersey, $662 \mathrm{p}$.

632 Zhuang, S.H., Wang, Z.Q., 2004. Influence of size, habitat and food concentration on the 633 feeding ecology of the bivalve, Meretrix meretrix Linnaeus. Aquaculture 241, 634 689-699. 
635

636 


\section{Captions to Figures}

640 Figure 1. Influence of phytoplankton-associated Co concentrations on whole-body 641 depuration kinetics of ${ }^{57} \mathrm{Co}$ in the oyster Isognomon isognomon and the clam Gafrarium 642 tumidum fed radiolabelled Isochrysis galbana $\left(10^{4}\right.$ cells $\left.\mathrm{ml}^{-1}\right) . \mathrm{A}(\%)$ : remaining activity

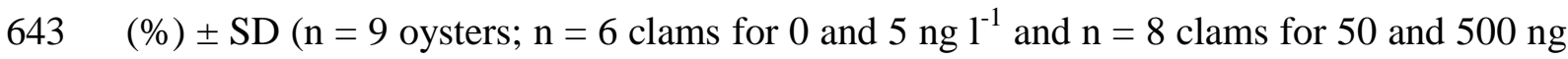
$\left.6441^{-1}\right)$.

646 Figure 2. Influence of phytoplankton species (Isochrysis galbana, Emiliania huxleyi and 647 Heterocapsa triquetra; $10^{4}$ cells $\mathrm{ml}^{-1}$ ) used as food on whole-body depuration kinetics of $648{ }^{54} \mathrm{Mn},{ }^{57} \mathrm{Co}$ and ${ }^{65} \mathrm{Zn}$ in the oyster Isognomon isognomon $(\mathrm{n}=9$ for I. galbana and 8 for $E$. 649 huxleyi and H. triquetra) and the clam Gafrarium tumidum ( $\mathrm{n}=8$ for I. galbana and 7 for 650 E. huxleyi and $H$. triquetra). A(\%): remaining activity $(\%) \pm \mathrm{SD}$.

652 Figure 3. Influence of phytoplankton cell density $\left(5 \times 10^{3}, 10^{4}\right.$ or $5 \times 10^{4}$ cells $\left.\mathrm{ml}^{-1}\right)$ on 653 whole-body depuration kinetics of ${ }^{54} \mathrm{Mn},{ }^{57} \mathrm{Co}$ and ${ }^{65} \mathrm{Zn}$ in the oyster Isognomon 654 isognomon $\left(\mathrm{n}=9\right.$ for $10^{4}$ cells $\mathrm{ml}^{-1}$ and $5 \times 10^{4}$ cells $\mathrm{ml}^{-1}$ ) and the clam Gafrarium 655 tumidum ( $\mathrm{n}=6$ for $5 \times 10^{3}$ cells $\mathrm{ml}^{-1}$ and $\mathrm{n}=8$ for $10^{4}$ cells $\mathrm{ml}^{-1}$ ) fed radiolabelled 656 Isochrysis galbana. $\mathrm{A}(\%)$ : remaining activity (\%) $\pm \mathrm{SD}$. 

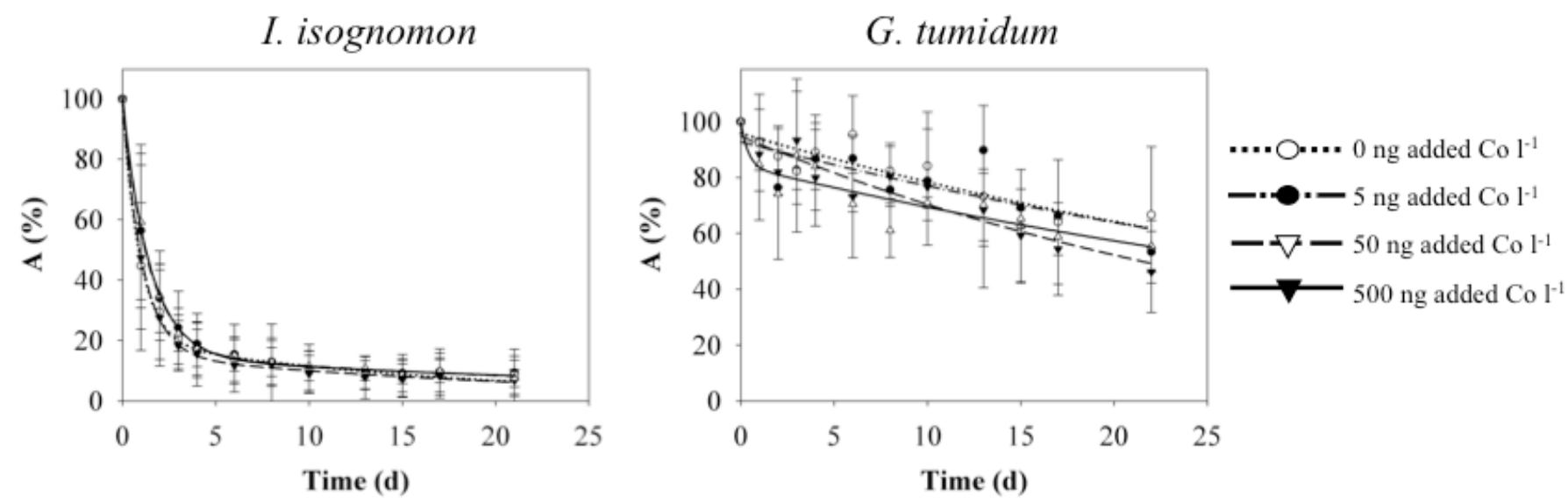

658

659

660

661

662

663

664

665 Fig. 1.

666

667 


\section{I. isognomon}
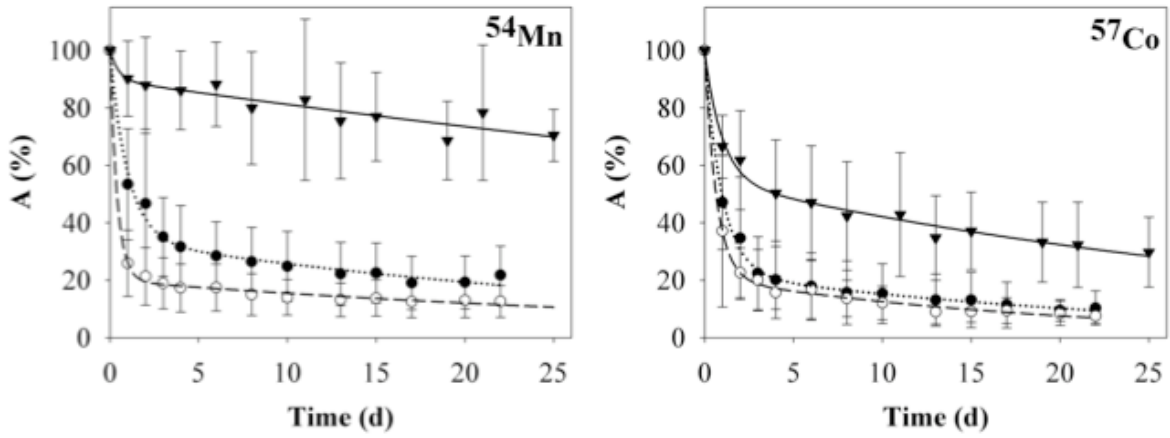

G. tumidum
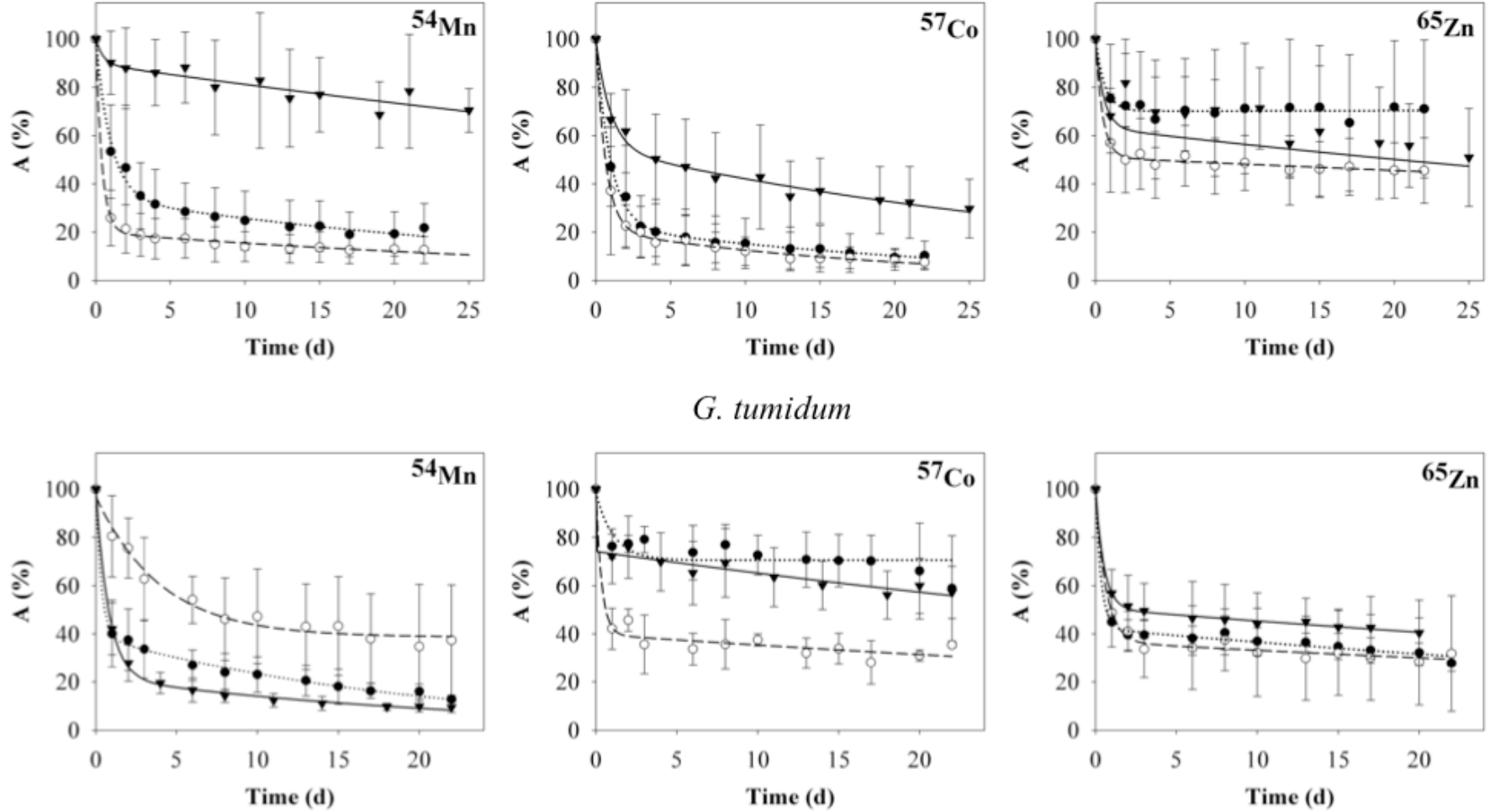

Phytoplankton species:

…..... E. huxleyi $\quad-$ - - H. triquetra I. galbana

675 Fig. 2.

676 


\section{I. isognomon}
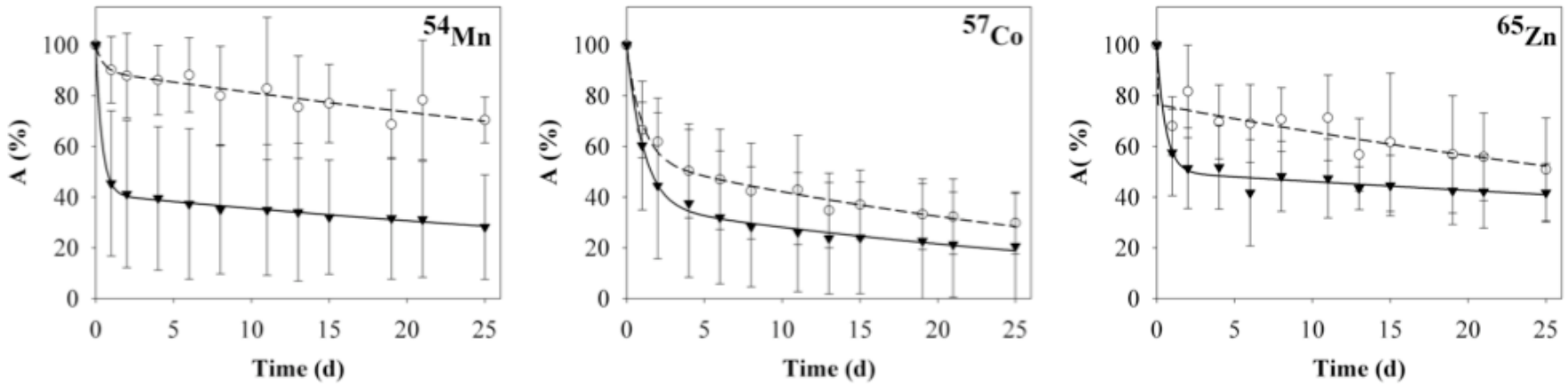

G. tumidum
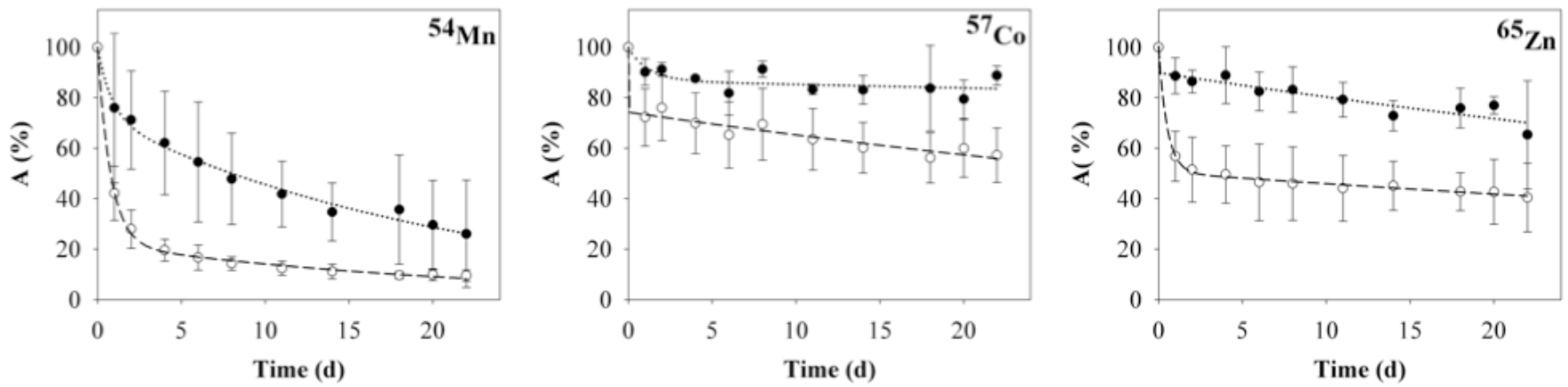

I. Galbana concentration:

$\cdots \cdot \cdots 510^{3}$ cells ml $\mathrm{ml}^{-1} \quad$ - $-\mathrm{O}-10^{4}$ cells $\mathrm{ml}^{-1} \longrightarrow 510^{4}$ cells ml$^{-1}$

682 Fig. 3 
Table 1. Assimilation efficiency (AE, \%), depuration rate constant $\left(\mathrm{k}_{\mathrm{el}}, \mathrm{d}^{-1}\right)$ and biological half-life $\left(\mathrm{T}_{\mathrm{b}^{1 / 2} / 2}, \mathrm{~d}\right)$ of ${ }^{57} \mathrm{Co}$ in the oyster Isognomon isognomon and the clam Gafrarium tumidum fed radiolabelled Isochrysis galbana $\left(10^{4}\right.$ cell $\left.\mathrm{ml}^{-1}\right)$ previously exposed to four increasing Co concentrations $(n=9$ oysters per concentration tested, $n=6$ clams for 0 and 5

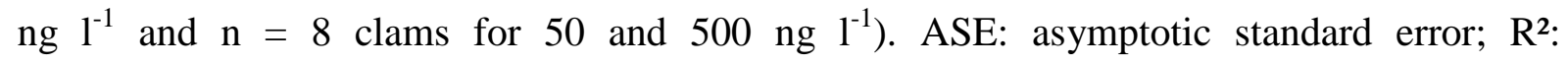
determination coefficient.

\begin{tabular}{|c|c|c|c|c|c|}
\hline Species & $\begin{array}{l}\text { Co concentration } \\
\text { added }\left(\mathrm{ng}^{-1}\right)\end{array}$ & $\mathrm{AE} \pm \mathrm{ASE}$ & $\mathbf{k}_{\mathrm{el}} \pm \mathrm{ASE}$ & $\mathbf{T}_{\mathbf{b}^{1 / 2 l}} \pm \mathbf{A S E}$ & $\mathbf{R}^{2}$ \\
\hline \multirow[t]{4}{*}{ I. isognomon } & 0 & $15.8 \pm 7.0^{\mathrm{a}}$ & $0.032 \pm 0.036^{*}$ & $22 \pm 24^{*}$ & 0.87 \\
\hline & 5 & $19.6 \pm 5.4^{\mathrm{c}}$ & $0.054 \pm 0.028 *$ & $13 \pm 7^{*}$ & 0.88 \\
\hline & 50 & $16.6 \pm 6.2^{b}$ & $0.050 \pm 0.036^{*}$ & $14 \pm 10 *$ & 0.86 \\
\hline & 500 & $14.7 \pm 6.0^{\mathrm{a}}$ & $0.027 \pm 0.033^{*}$ & $25 \pm 30 *$ & 0.90 \\
\hline \multirow[t]{4}{*}{ G. tumidum } & 0 & $77.2 \pm 3.9^{\mathrm{d}}$ & $0.018 \pm 0.006^{\mathrm{b}}$ & $37 . \pm 11^{\mathrm{b}}$ & 0.64 \\
\hline & 5 & $77.4 \pm 3.9^{\mathrm{d}}$ & $0.019 \pm 0.006^{\mathrm{c}}$ & $36 \pm 10^{c}$ & 0.27 \\
\hline & 50 & $75.7 \pm 3.9^{d}$ & $0.018 \pm 0.006^{\mathrm{b}}$ & $39 \pm 12^{b}$ & 0.51 \\
\hline & 500 & $84.1 \pm 5.9^{d}$ & $0.019 \pm 0.007^{\mathrm{a}}$ & $36 \pm 13^{a}$ & 0.51 \\
\hline
\end{tabular}

Significance of the estimated parameters: ${ }^{\mathrm{a}} \mathrm{p}<0.05,{ }^{\mathrm{b}} \mathrm{p}<0.01,{ }^{\mathrm{c}} \mathrm{p}<0.001,{ }^{\mathrm{d}} \mathrm{p}<0.0001, *$ not significant $(\mathrm{p}>0.05)$ 
Table 2. Assimilation efficiency (AE, \%), depuration rate constant $\left(\mathrm{k}_{\mathrm{el}}, \mathrm{d}^{-1}\right)$ and biological half-life, $\left(\mathrm{T}_{\mathrm{b}^{1 / 2} / 1}, \mathrm{~d}\right)$ of ${ }^{54} \mathrm{Mn},{ }^{57} \mathrm{Co}$ and ${ }^{65} \mathrm{Zn}$ in the oyster Isognomon isognomon and the clam Gafrarium tumidum fed radiolabelled Emiliania huxleyi $\left(10^{4}\right.$ cell $\left.\mathrm{ml}^{-1}\right)$, Heterocapsa triquetra $\left(10^{4}\right.$ cell ml $\left.\mathrm{m}^{-1}\right)$ and Isochrysis galbana $\left(10^{4}\right.$ cell ml $\mathrm{m}^{-1}$ and $510^{4}$ cell ml $\mathrm{m}^{-1}$ for I. isognomon; $510^{3}$ cell $\mathrm{ml}^{-1}$ and $10^{4}$ cell $\mathrm{ml}^{-1}$ for $G$. tumidum) ( $\mathrm{n}=8$ oysters; $\mathrm{n}=7$ clams per phytoplankton species tested). ASE: asymptotic standard error; $\mathrm{R}^{2}$ : determination coefficient.

\begin{tabular}{|c|c|c|c|c|c|c|c|}
\hline Species & $\begin{array}{l}\text { Phytoplankton } \\
\text { strain }\end{array}$ & $\begin{array}{l}\text { Cell density } \\
\left(\text { cells } \mathrm{ml}^{-1}\right)\end{array}$ & Isotope & $\overline{\mathrm{AE}} \pm \mathrm{ASE}$ & $\mathrm{k}_{\mathrm{el}} \pm \mathrm{ASE}$ & $\mathbf{T}_{\mathbf{b}^{1 / 2 l}} \pm \mathrm{ASE}$ & $\overline{\mathbf{R}^{2}}$ \\
\hline \multirow[t]{12}{*}{ I. isognomon } & \multirow[t]{3}{*}{ E. huxleyi } & $10^{4}$ & ${ }^{54} \mathrm{Mn}$ & $34 \pm 6.5^{d}$ & $0.028 \pm 0.015^{*}$ & $24 \pm 13^{*}$ & 0.74 \\
\hline & & $10^{4}$ & ${ }^{57} \mathrm{Co}$ & $22 \pm 5.6^{c}$ & $0.039 \pm 0.021 *$ & $18 \pm 10^{*}$ & 0.83 \\
\hline & & $10^{4}$ & ${ }^{65} \mathrm{Zn}$ & $70 \pm 6.5^{d}$ & $0.0002 \pm 0.007^{*}$ & $2783^{*}$ & 0.11 \\
\hline & \multirow[t]{3}{*}{ H. triquetra } & $10^{4}$ & ${ }^{54} \mathrm{Mn}$ & $20 \pm 2.6^{d}$ & $0.025 \pm 0.012^{\mathrm{a}}$ & $28 \pm 13^{a}$ & 0.92 \\
\hline & & $10^{4}$ & ${ }^{57} \mathrm{Co}$ & $21 \pm 4.1^{\mathrm{d}}$ & $0.050 \pm 0.020^{\mathrm{a}}$ & $14 \pm 6^{\mathrm{a}}$ & 0.88 \\
\hline & & $10^{4}$ & ${ }^{65} \mathrm{Zn}$ & $51 \pm 3.2^{\mathrm{d}}$ & $0.006 \pm 0.005^{*}$ & $123 \pm 109 *$ & 0.57 \\
\hline & \multirow[t]{6}{*}{ I. galbana } & $10^{4}$ & ${ }^{54} \mathrm{Mn}$ & $90 \pm 5.6^{d}$ & $0.010 \pm 0.005^{\mathrm{a}}$ & $70 \pm 32^{a}$ & 0.23 \\
\hline & & $10^{4}$ & ${ }^{57} \mathrm{Co}$ & $55 \pm 7.1^{\mathrm{d}}$ & $0.026 \pm 0.010^{b}$ & $26 \pm 10^{b}$ & 0.63 \\
\hline & & $10^{4}$ & ${ }^{65} \mathrm{Zn}$ & $76 \pm 4.1^{\mathrm{d}}$ & $0.015 \pm 0.004^{b}$ & $45 \pm 13^{b}$ & 0.36 \\
\hline & & $510^{4}$ & ${ }^{54} \mathrm{Mn}$ & $41 \pm 7.8^{d}$ & $0.015 \pm 0.014^{*}$ & $47 \pm 46^{*}$ & 0.38 \\
\hline & & $510^{4}$ & ${ }^{57} \mathrm{Co}$ & $37 \pm 21 *$ & $0.027 \pm 0.043^{*}$ & $26 \pm 42 *$ & 0.51 \\
\hline & & $510^{4}$ & ${ }^{65} \mathrm{Zn}$ & $52 \pm 3.5^{\mathrm{d}}$ & $0.010 \pm 0.005^{\mathrm{a}}$ & $70 \pm 34^{a}$ & 0.60 \\
\hline \multirow[t]{12}{*}{ G. tumidum } & \multirow[t]{3}{*}{ E. huxleyi } & $10^{4}$ & ${ }^{54} \mathrm{Mn}$ & $39 \pm 4.3^{d}$ & $0.051 \pm 0.011^{\mathrm{d}}$ & $14 \pm 3^{d}$ & 0.92 \\
\hline & & $10^{4}$ & ${ }^{57} \mathrm{Co}$ & $80 \pm 3.5^{d}$ & $0.010 \pm 0.004^{\mathrm{a}}$ & $70 \pm 26^{a}$ & 0.47 \\
\hline & & $10^{4}$ & ${ }^{65} \mathrm{Zn}$ & $42 \pm 2.3^{\mathrm{d}}$ & $0.014 \pm 0.004^{\mathrm{b}}$ & $48 \pm 14^{b}$ & 0.93 \\
\hline & \multirow[t]{3}{*}{ H. triquetra } & $10^{4}$ & ${ }^{54} \mathrm{Mn}$ & $56 \pm 23^{a}$ & $0.021 \pm 0.026^{*}$ & $34 \pm 10^{*}$ & 0.61 \\
\hline & & $10^{4}$ & ${ }^{57} \mathrm{Co}$ & $41 \pm 3.1^{\mathrm{d}}$ & $0.014 \pm 0.006^{\mathrm{a}}$ & $49 \pm 9^{a}$ & 0.89 \\
\hline & & $10^{4}$ & ${ }^{65} \mathrm{Zn}$ & $33 \pm 7.3^{d}$ & $0.005 \pm 0.016^{*}$ & $143 \pm 474 *$ & 0.71 \\
\hline & \multirow[t]{6}{*}{ I. galbana } & $10^{4}$ & ${ }^{54} \mathrm{Mn}$ & $22 \pm 3.7^{\mathrm{d}}$ & $0.044 \pm 0.015^{b}$ & $16 \pm 5^{b}$ & 0.65 \\
\hline & & $10^{4}$ & ${ }^{57} \mathrm{Co}$ & $73 \pm 2.7^{d}$ & $0.010 \pm 0.003^{b}$ & $68 \pm 21^{b}$ & 0.33 \\
\hline & & $10^{4}$ & ${ }^{65} \mathrm{Zn}$ & $51 \pm 3.8^{\mathrm{d}}$ & $0.013 \pm 0.006^{\mathrm{a}}$ & $55 \pm 25^{\mathrm{a}}$ & 0.52 \\
\hline & & $510^{3}$ & ${ }^{54} \mathrm{Mn}$ & $72 \pm 17.9^{c}$ & $0.046 \pm 0.021^{\mathrm{a}}$ & $15 \pm 7^{\mathrm{a}}$ & 0.98 \\
\hline & & $510^{3}$ & ${ }^{57} \mathrm{Co}$ & $87 \pm 6.1^{d}$ & $0.002 \pm 0.005^{*}$ & $416 \pm 135^{*}$ & 0.47 \\
\hline & & $510^{3}$ & ${ }^{65} \mathrm{Zn}$ & $90 \pm 3.0^{\mathrm{d}}$ & $0.011 \pm 0.003^{c}$ & $61 \pm 16^{c}$ & 0.68 \\
\hline
\end{tabular}

Significance of the estimated parameters: ${ }^{\mathrm{a}} \mathrm{p}<0.05,{ }^{\mathrm{b}} \mathrm{p}<0.01,{ }^{\mathrm{c}} \mathrm{p}<0.001,{ }^{\mathrm{d}} \mathrm{p}<0.0001$, * not significant $(\mathrm{p}>0.05)$ 